\title{
The Testing New Traditional Market Location in Padang City (Case Study the Location between Simpang Haru Market and the Bandar Buat Market)
}

\author{
Yosi Suryani \\ \{yosisuryani@pnp.ac.id\} \\ Politeknik Negeri Padang, Indonesia
}

\begin{abstract}
This article aims to examine three locations for the construction of a new traditional market in Padang City. That is the location between Simpang Haru Market and Bandar Buat Market. The test results provide recommendations on whether or not the location requires a new traditional market. The method used is testing the new location with the AHP (Analytical Hierarchy Process) and the assessment indicator consists of the population, location development measured by socio-economic changes, people's spending habits around the location of the people's market development plan, the purchasing power of residents around the location of market development plans people, differences in social status, number, area, type and location of old markets, accessibility, and physical condition of the natural environment around the planned location of the construction of a new people's market. The results of the study concluded that the testing of the location between the Simpang Haru Market and the Bandar Buat Market resulted in a range of judgments that were in a position quite high. Figures with a fairly high predicate provide recommendations that in these locations require a traditional maid market that can serve the needs of society optimally.
\end{abstract}

Keywords: The Testing, Traditional Market Location, Padang City

\section{Introduction}

The intensity and variety of activities that occur in a traditional market characterize how economic activity in a city runs. The higher the activity that occurs in the traditional market is one indicator of the increasingly dynamic rotation of the city's economic wheels. As an effort to make traditional markets as one of the driving forces of the dynamics of economic development in a city, it is necessary to have traditional markets that can operate optimally and efficiently and can serve the needs of the community. Efficiency and optimization of the service of a traditional market can be seen, among others, from the pattern of distribution of trading facilities, time of market service, physical condition of the market and the variety of traded goods and the traditional market (institutional) market management system itself.

Padang City has 16 (sixteen) traditional markets spread over 11 (eleven) sub-districts and 1 (one) trade center, namely Raya Padang Market. But in 2017 according to the survey results, there were only 15 (fifteen) traditional markets in Padang city, because 1 (one) traditional market location no longer operated with the expansion of tsunami evacuation routes. The 
location of a traditional market in one sub-district has more than one traditional market and has a short distance, which causes one side of the high level of visits to the traditional market, but visits to other traditional markets that are close together are low. Another condition is the population growth of Padang City tends to be higher towards the east, but representative traditional markets are not yet owned, or the distance between one traditional market and another traditional market is very far away, so that the existing traditional market is unable to accommodate a high number of visits which in the end inconvenience to buyers. The results of previous research Suryani [1] there are three locations in Padang City that are recommended to be tested whether or not to build a new traditional market or not, because the distance between the nearest traditional market is quite far. The location is the location between Simpang Haru Market and Bandar Buat Market, the location between the Belimbing Market and the Siteba Market and the location between the Ulak Karang Market and the Lubuk Buaya Market. This article will discuss about testing a location for a traditional market development plan in Padang City, which is the location between Simpang Haru Market and Bandar Buat Market.

\section{Literature Review}

\subsection{Traditional Market Location}

In the case of selecting the location of the construction, the market should be established in a crowded and wide location. Establishment of a market in a location where there is no trading activity, it is very difficult to expect to be visited by the community. While the population, income per capita, income distribution, agglomeration and government policy also greatly influence the determination of the location of an activity [2]. Areas with large population are markets that need attention.

According to Dewar et. all [3] location is an important factor and influences the success of the traditional market. Three main factors that influence the location of traditional markets for city scale are: (1) Location of generator of population movement (locations that cause population / people movement).A market is able to develop well because it is in a location that is so close to the movement of many people. The most successful market is in the Central Business District (CBD) and other formal traders. Industrial centers / concentrations, around public transport terminals (bus terminals, train stations, etc.) and locations that have a high population density, (2) Sources of supply (location that is close to the sources of stock of goods sold), (3) Location of customers (location close to the buyer/market user).

According to De Chiara [4], adding the criteria that must be met in determining the location of markets/shopping centers are: (1) Proximity to market share, (2) Proximity to raw materials, (3) availability of electricity and water, (4) Climate, (5) Availability of capital, (6) Fire protection, police protection, health services, (7) Housing/residential areas, (8) Local regulations, (9). City growth in the future.

In addition to the things that have been raised by De Chiara [4], the things that must be considered in determining the location of the market are: (1) Population in the trade area, including the composition and its growth, (2) City development that can be measured by socio-economic changes, (3) population shopping habits, (4) population purchasing power can be seen from the number of workers, type of work, level of income and amount of savings held, (5) Differences in social status can be seen from the type of house, house ownership, level of education and number of vehicle ownership, (6) Amount, area, type and location of old markets, (7) Accessibility in the form of public transportation facilities, proximity to potential customers can be in the form of regions housing and offices, (8) Physical condition 
of nature, can be seen from topography, geological conditions, disaster prone and so on. Determining the location in the city varies greatly, including the principle of minimum costs, efficiency, and median location, transportation routes, sources of marketing raw materials and population are factors that must be taken into account. This was also strengthened by Blair [5] in his research. Local economic Development: Analysis and Practice. California, USA: Sage Publication Inc.

Suryani [6] explained in the results of her research that Padang City, the location of traditional markets in Padang City, was completely able to reach and provide optimal services for the people in the vicinity. There are three traditional market locations that need to be tested about the addition of new traditional markets. The distance factor and the wide range of traditional market coverage from one another are far enough and there is no wide slice of coverage which is a factor considering the need to increase the new traditional market in Padang City.

\subsection{Accessibility}

According to Black in Tamin [7], accessibility is a measure of comfort or convenience about how land use locations interact with each other and the ease or difficulty of the location is achieved through a transportation network system. Accessibility is a concept that combines a geographical land use regulation system with a transportation network system that connects it. So it can be said here that accessibility reflects the distance of movement between several places that can be measured by the time and/or costs needed for the transfer.

Jayadinata [8] added that there are several policy alternatives carried out by the government in improving the accessibility of an area, so that the population in various circumstances can reach the social and economic services needed, namely: (1) Helping individual mobility (to work, school, market, treatment centers and so on), (2) Providing service activities for residents (mobile services: health, libraries and so on), (3) Relocating people to be close to the center of activity: markets, schools and so on, (4) Adding transportation services, (5) Relocating activities (to be close to the population), (6) Conducting a policy on time (for various activities, and for scheduling time such as for: rush hours for schools, markets, clinics and so on).

\section{Methods}

The research location is in Padang City, namely the area between Simpang Haru Market and Bandar Buat Market. Data collection techniques are structured interviews using questionnaires. Questionnaires were given to the respondent in this case the researchers themselves and the community to assess the level of their perception of the planned construction of a new traditional market between Simpang Haru Market and Bandar Buat Market.

Data analysis method is using AHP (Analysis Hierarchy Process) analysis, that is by defining the problem, creating a hierarchical structure, arranging pairwise appeal matrix, arranging logical consistency, mathematical formula, prioritizing synthesis to weight priority vectors, and evaluating inconsistencies for all hierarchy. Indicators used to assess the location of new traditional market development plans are population, location of socio-economic changes, spending habits of the surrounding population, purchasing power of people around the location, differences in social status, number, size, type and location of old markets, modern market conditions, accessibility, physical condition of nature around the location of the market development plan. 
The results of the assessment of the three new traditional market development plan locations are then multiplying the weight by the score of each factor used to measure the feasibility of a new traditional market location. The score used is 1 to 5 (Likert Scale) and the value obtained is the total value of each location tested. The assessment is carried out by researchers when conducting surveys and observations directly in the area between Pasar Simpang Haru and Bandar Buat Market.

The final value obtained from the results of the multiplication between the weights with the scores of the 9 (nine) factors assessed, the range of values based on the level can be seen in Table 1.

Table 1. Range of Values for Assessment of New Traditional Market Locations

\begin{tabular}{|c|c|c|}
\hline No & Range of Value & Category \\
\hline 1 & $801-1000$ & Very High \\
\hline 2 & $601-800$ & High \\
\hline 3 & $401-600$ & High Enough \\
\hline 4 & $201-400$ & Poor \\
\hline 5 & $0-200$ & Very Poor \\
\hline
\end{tabular}

\section{Discussion}

Each traditional market gives birth to a wide range of coverage drawn in the form of a circle drawn from the center of each traditional market. Communities that are included in the broad scope are people who use these traditional markets to obtain their living needs. When an incision occurs, the community in the slice visits the markets that make up the slice. Communities outside the slices are people who have not yet received optimal services by the traditional markets that are nearby. With these conditions it needs to be tested whether it is necessary to add a new traditional market that serves as a supporting market among traditional markets that exist or need other efforts so that the community that is outside the broad slices of traditional market coverage obtained in previous research gets optimal service by the traditional markets nearby.

Before evaluating the location of the new traditional market development plan by the researcher, it is necessary to do mathematical calculations of each stage for the selection of three locations of each planned traditional market. This is done using the AHP (Analytical Hierarchy Process) method. After going through nine mathematical stages, the value of $\mathrm{CI}=$ 0.067 is obtained, with a matrix size of 9 , the value of the Random Index (RI) taken is 1.5 . So the CR value is $4.49 \%$ smaller than $10 \%$, so the results of decision making are acceptable.

\section{Analysis of Researchers on the Location of the New Traditional Market between Simpang Haru Market and Bandar Buat Market}


Before assessing the location, the factors and indicators in the location assessment as previously discussed in the methodology are determined first. Furthermore, the planned market location between Pasar Simpang Haru and Bandar Buat Market (location in Cengkeh), based on the indicators fulfilled, is given a score / rating with a rating scale of 1 (one), 2 (two), 3 (three), 4 (four) and 5 (five), where: Value 5: given if the factors assessed in the prospective location meet the criteria for the predetermined indicator standard, Value 4: given if the factors are assessed on prospective locations that meet the criteria for predetermined indicator standards, Value 3: given if factors are assessed on prospective locations that are sufficient to meet the criteria for predetermined indicator standards, Value 2: given if the factors are assessed on prospective locations that do not meet the criteria for predetermined indicator standards and Value 1 : given if the factors that are assessed on prospective locations that do not meet the criteria for the predetermined indicator standards.

From the results of the AHP analysis, we get the weighting for each factor, as in Table 2.

\begin{tabular}{|c|l|c|c|c|c|c|c|c|c|c|c|}
\hline No & \multicolumn{1}{|c|}{ Factor } & 1 & 2 & 3 & 4 & 5 & 6 & 7 & 8 & 9 & Wi(Weight) \\
\hline 1 & Population & 1.00 & 1.17 & 0.61 & 1.17 & 1.76 & 0.46 & 2.13 & 2.15 & 4.36 & 14.80 \\
\hline 2 & $\begin{array}{l}\text { Location development of socio-economic } \\
\text { changes }\end{array}$ & 0.85 & 1.00 & 0.52 & 1.00 & 1.50 & 0.39 & 1.81 & 1.84 & 3.72 & 12.62 \\
\hline 3 & $\begin{array}{l}\text { Shopping habits of the surrounding } \\
\text { population }\end{array}$ & 1.65 & 1.93 & 1.00 & 1.92 & 2.90 & 0.75 & 3.50 & 3.54 & 7.18 & 24.38 \\
\hline 4 & $\begin{array}{l}\text { Purchasing power of residents around } \\
\text { the location }\end{array}$ & 0.86 & 1.00 & 0.52 & 1.00 & 1.51 & 0.39 & 1.82 & 1.84 & 3.74 & 12.69 \\
\hline 5 & Difference in social status & 0.57 & 0.67 & 0.34 & 0.66 & 1.00 & 0.26 & 1.21 & 1.22 & 2.47 & 8.40 \\
\hline 6 & $\begin{array}{l}\text { Number, area, type and location of old } \\
\text { markets }\end{array}$ & 2.19 & 2.57 & 1.33 & 2.55 & 3.85 & 1.00 & 4.65 & 4.71 & 9.54 & 32.39 \\
\hline 7 & Modern Market Conditions & 0.47 & 0.55 & 0.29 & 0.55 & 0.83 & 0.22 & 1.00 & 1.01 & 2.05 & 6.97 \\
\hline 8 & Accessibility & 0.46 & 0.54 & 0.28 & 0.54 & 0.82 & 0.21 & 0.99 & 1.00 & 2.03 & 6.88 \\
\hline & $\begin{array}{l}\text { The physical condition of nature around } \\
\text { the location of the market development }\end{array}$ & & & & & & & & & & \\
\hline 9 & \begin{tabular}{l} 
plan \\
\hline
\end{tabular} & 0.23 & 0.27 & 0.14 & 0.27 & 0.40 & 0.10 & 0.49 & 0.49 & 1.00 & 3.40 \\
\hline
\end{tabular}

Table 2. Weight for each factor

After the weighting for each of the factors obtained from the AHP method, the next step in the location assessment is to assess the location of the planned construction of a new traditional market between Simpang Haru Market and Bandar Buat Market, namely the Clove area. This assessment was carried out by researchers who made direct observations to the intended object, namely the Clove Market which was included in the shocked market category. The score for the location between the Simpang Haru Market and the Bandar Buat Market, namely the Clove area, can be described in Table 3.

Each factor is given a weight and multiplied by the score of each factor, so that the value of each factor is used as a measuring tool. Each value from the results of the weight multiplication with the score, then obtained the total value of the location between the Simpang Haru Market and Bandar Market for the researcher is 521.32. When viewed in the range of values described in the methodology, the location in the Clove area between the Simpang Haru Market and the Bandar Market for the results of the assessment of the researchers is in a high enough position. This indicates that the location allows the construction of a new traditional market to serve the community which is beyond the scope of 
the nearest traditional market, namely the Simpang Haru Market with the Bandar Buat Market.

Table 3. Researcher Assessment of Location Plans for New Traditional Market Development Between Simpang Haru Market and Bandar Buat Market

\begin{tabular}{|c|l|c|c|c|}
\hline \multirow{2}{*}{ No } & \multicolumn{1}{|c|}{ Factor } & \multirow{2}{*}{ Weight } & \multicolumn{2}{c|}{ Researcher's assessment } \\
\cline { 5 - 5 } & & 14.80 & 4 & 59.20 \\
\hline 1 & Population & 12.62 & 4 & 50.50 \\
\hline 2 & Location development of socio-economic changes & 24.38 & 5 & 121.89 \\
\hline 3 & Shopping habits of the surrounding population & 12.69 & 4 & 50.75 \\
\hline 4 & Purchasing power of residents around the location & 8.40 & 4 & 33.61 \\
\hline 5 & Difference in social status & 32.39 & 4 & 129.55 \\
\hline 6 & Number, area, type and location of old markets & 6.97 & 4 & 27.86 \\
\hline 7 & Modern Market Conditions & 6.88 & 5 & 34.39 \\
\hline 8 & Accessibility & & & \\
\hline 9 & $\begin{array}{l}\text { The physical condition of nature around the location of the } \\
\text { market development plan }\end{array}$ & 3.40 & 4 & 13.58 \\
\hline & Amount & $\mathbf{1 2 2 . 5 2}$ & & $\mathbf{5 2 1 . 3 2}$ \\
\hline
\end{tabular}

This score indicates that the location between the Simpang Haru Market and the Bandar Market has the potential to be developed with the construction of a new traditional market that serves as an auxiliary market to serve people outside the broad slice of traditional market coverage according to the results of previous research conducted by Suryani [1].

\section{Conclusions}

The results of the analysis of the researchers' assessment of the location between Pasar Simpang Haru and Pasar Bandar make conclusions about the location between Pasar Simpang Haru and Bandar Buat requiring a traditional maid market to serve the people in the area. The area or location that is suitable for the construction of a new traditional market is the Clove area, because this location does not occur, or a meeting between the wide coverage between the Simpang Haru Market and the Bandar Buat Market. After an assessment by the researcher, the location between Simpang Haru Market and Bandar Buat Market is recommended for the construction of supporting market.

\section{References}

[1] Suryani, Yosi. Analysis of Market Boundaries on Traditional Market Places Managed by Local Government in Padang. International Journal of Applied Business and Economic Research, Vol 
14, Number 11 (2016).

[2] Djojoadipuro, Marsudi. Location Theory. Institute of Publishers of the Faculty of Economics, University of Indonesia (1992).

[3] Dewar, David and Watson, Venessa. Urban Market Developing Informal Retailing. London, Rontledge (1990).

[4] De Chiara, J. Koppelman. Site Planning Standards. Publisher of Erlangga (1999).

[5] Blair, Jhon P. Local economic Development: Analysis and Practice. California, USA: Sage Publication Inc. (1995).

[6] Suryani, Yosi. An Empirical Study pf The Spatial Demand and Market Area /1 The Case of Market Places in Padang City. International Journal of Physical and Social Science. ISSN: 2249-5894 (2015).

[7] Isya, M. Tamin. Analysis of the Function of Travel Constraints in Determining the Origin-Destination Matrix (MAT). Proceeding,of Unibraw. Surabaya (2000).

[8] Jayadinata, Johara T. The Planning of Village Development. Bandung: ITB (1985). 